\title{
ILONA ŻEBER-DZIKOWSKA
}

Zakład Zoologii i Dydaktyki Biologii, Instytut Biologii, Uniwersytet Jana Kochanowskiego w Kielcach

\section{ELŻBIETA BUCHCIC}

Zakład Zoologii i Dydaktyki Biologii, Instytut Biologii, Uniwersytet Jana Kochanowskiego w Kielcach

\section{Etyczny wymiar myślenia i działania ekologicznego w edukacji wczesnoszkolnej}

Słowa kluczowe: ekoetyka, edukacja przyrodnicza, świadomość ekologiczna, cele edukacji ekologicznej

Key words: environmental ethics, environmental education, environmental awareness, aims of environmental education

\section{SUMMARY \\ The ethical dimension of ecological thinking and action in early childhood education}

This paper provides an analysis of selected topics in the field of eco-ethics. The school should be more involved in the protection of the natural environment, mainly by shaping truly responsible attitudes. Ecological education must become an integral part of a person's upbringing. The aim of education should be to create and develop correct pro-ecological attitudes, which are opposed to the uncontrolled exploitation of natural resources. Environmental sustainability is only possible if people are persuaded to give up the consumer lifestyle (the so-called ecological asceticism). 


\section{Wstęp}

„Nieograniczony rozwój gospodarczy i postęp techniki, przy słabej ochronie przyrody, grozi światu klęską ekologiczną” (Skrzeszewski 1981: 225). Żyjemy w społeczeństwie ryzyka samozniszczenia ludzkości. Często podkreśla się, że niekontrolowany postęp techniczny i ekonomiczny, traktowany jako wartość absolutna, nie liczący się z podstawowymi prawami przyrody musiał doprowadzić do globalnego kryzysu ekologicznego. „Jest oczywiste - podkreślał Jan Paweł II - że niekontrolowany rozwój przemysłowy oraz zastosowanie technologii naruszających równowage środowiska naturalnego, to przyczyny ogromnych szkód i tragicznych katastrof” (Jan Paweł II 1993a: 4). W przemówieniu do ludzi kultury i nauki wymienił wśród wielu dramatów współczesnego świata, takich jak przemoc, nietolerancja, głód i bieda miliona osób, także i klęskę ekologiczną o takich rozmiarach, że istnieje obawa holokaustu środowiska naturalnego, nie mniej przerażającego niż holokaust nuklearny.

W innym przemówieniu podkreślał: „(...) zagrożenia o charakterze planetarnym osiągnęły poziom skrajnie niebezpieczny, co każe się obawiać zagłady ekologicznej, będącej skutkiem lekkomyślnego niszczenia najważniejszych zasobów środowiska" (Jan Paweł II 1993b: 14)). Zniszczenie środowiska przyrodniczego jest przekonującym dowodem na to, że człowiek nie może wykazywać egoistycznej postawy wobec przyrody, eksploatować Ziemi bez przewidywania skutków swoich działań.

Degradacja środowiska jest tragicznym przejawem i skutkiem wielorakich form zbiorowego egoizmu, żądzy posiadania i kierowania się przemocą w stosunku do wszystkich niższych postaci życia (Podrez 1991: 78).

Podejmowane $\mathrm{w}$ artykule analizy wybranych zagadnień $\mathrm{z}$ ekoetyki nawiązują głównie do źródeł z zakresu społecznej nauki Kościoła. 


\section{Rozważania nad kryzysem ekologicznym w aspekcie etycznym - uwzględniając człowieka $w$ jego relacji do środowiska naturalnego}

Niektóre szkody ekologiczne są już nieodwracalne, ale wiele procesów można jeszcze zatrzymać. Człowiek musi nauczyć się nowego odniesienia do świata istot żywych i świata rzeczy, musi nauczyć się być odpowiedzialnym. Największe niebezpieczeństwo tkwi bowiem w samym człowieku, który dysponując coraz to potężniejszymi środkami, może je wykorzystywać w niewłaściwy sposób. Postęp techniczny, działalność badawczo-naukowa, sposoby produkcji nie mogą być traktowane jako neutralne etycznie: „(...) wobec zanieczyszczenia ziemi i powietrza, rzek i mórz, niszczenia flory i fauny przez produkty naszej technicznej cywilizacji, i wobec zagrożeń wynikających z możliwości manipulowania technikami genetycznymi, koniecznie trzeba przywrócić równowagę między nauką i sumieniem. Sama nauka musi kierować się (...) podstawowymi prawami człowieka, nastawić się na służenie jego prawdziwemu dobru, a także ochronę i ratowanie dewastowanej przyrody. Od tej odpowiedzialności nauka uchylić się nie może" (Jan Paweł II 1993b: 28).

Kwestia ekologiczna dzisiaj wymaga zmiany orientacji, zwrotu w myśleniu, przeobrażeniu mentalności i działań, aby ocalić przyrodę i świat nas otaczający. Rozważania nad kryzysem ekologicznym należy więc prowadzić w aspekcie etycznym, uwzględniając człowieka w jego relacji do środowiska przyrodniczego.

Ekoetyka podkreśla jedność człowieka i jego środowiska, odpowiedzialność za świat i jego przyszłość, konieczność kształtowania właściwych postaw proekologicznych. Etyczny wymiar naszego myślenia i działania w kwestii ekologii jest niezbędny.

„Ponieważ człowiek, staje naprzeciw naturze, nie przestaje być jej cząstką, troskliwe obchodzenie się z naturą uznajemy za warunki godnej człowiekowi egzystencji oraz jako nakaz. Gdy dziś wyraźniej niż do niedawna napotykamy granice $\mathrm{w}$ naturze, to należy to interpretować jako wezwanie, by uznać także własne granice, skończoność osoby, 
a wraz z tym także granice naszej chęci posiadania, naszej zdolności czynienia, naszego zewnętrznego rozwoju. Razem z odkryciem takich granic uświadamiamy sobie odpowiedzialność, jaką ponosimy za przyszłe pokolenia. Nakaz uprawiania ziemi zawiera także zobowiązanie pozostawienia następnym generacjom takiego świata, w którym możliwe będzie godne człowieka życie" (Sutor 1994: 362-363).

Skoro kwestia ekologiczna wiąże się ściśle z kształtowaniem świadomości moralnej, to szkoła powinna się zaangażować w obronę środowiska przyrodniczego, głównie przez kształtowanie prawdziwie odpowiedzialnej postawy. Wychowanie ekologiczne musi się stać integralną częścią wychowania człowieka już od najmłodszych lat. Celem edukacji powinno być kształtowanie postaw proekologicznych, które będą występować przeciw niekontrolowanej eksploatacji zasobów, które będą wykazywać troskę o środowisko przyrodnicze. Prawidłowa równowaga ekologiczna jest możliwa do osiągnięcia jedynie wtedy, gdy ludzie będą przekonani o konieczności rezygnacji z konsumpcyjnego stylu życia (tzw. asceza ekologiczna). W takich warunkach wydaje się nieuniknione wprowadzanie nowych norm etycznych zwanych ekoetyką.

\section{Główne założenia ekoetyki}

Ekoetyka chce przejawiać się w każdej dziedzinie życia, pragnie wpływać na pracę, edukację, życie towarzyskie, hobby, sposób spędzania wolnego czasu. W praktyce oznacza to sprzeciw wobec kreowania sztucznych potrzeb, rozbudzaniu konsumpcji. Dlatego preferowane są turystyka i formy rekreacji możliwie najmniej ingerujące w środowisko. Konsekwentnie rezygnuje się z nadmiernej i nieuzasadnionej budowy infrastruktury.

Ekoetyka postuluje poszanowanie bytów tworzących widzialną naturę, którą Grecy nazywali kosmosem, czyli porządkiem. Ta rzeczywistość wymaga poszanowania z trzech względów. Po pierwsze: istnieje konieczność lepszego uświadomienia sobie, że nie można bezkarnie używać różnego rodzaju dóbr naturalnych, żyjących lub nieożywionych, 
składników naturalnych, roślin i zwierząt w sposób dowolny, według własnych potrzeb ekonomicznych. Należy brać pod uwagę naturę i przeznaczenie każdego bytu oraz wzajemne powiązania w uporządkowany system, którym jest cały kosmos. Drugi postulat opiera się na fakcie ograniczoności zasobów naturalnych, z których część nie odnawia się. Używanie ich tak jakby były niewyczerpalne, naraża na niebezpieczeństwo możliwości korzystania z nich przez przyszłe pokolenia. Trzeci postulat odnosi się do skutków jakie pociąga za sobą rozwój w sferach uprzemysłowionych. Wiadomo, że jest to coraz większe zatrucie środowiska, niosące poważne konsekwencje dla zdrowia i życia człowieka (Jan Paweł II 1997: 34). Ekoetyka niejako odpowiada na powyższe postulaty. Jej program można przedstawić w trzech zasadach działania człowieka. "Być" czy „mieć" - zasada nowej jakości życia; pierwsza z nich: zasada nowej jakości życia, przeciwstawia mentalności konsumpcji pewną uporządkowaną hierarchię wartości. Nadmierna rozporządzalność dobrami naturalnymi i materialnymi łatwo przemienia ludzi w niewolników posiadania i natychmiastowego zadowolenia, którzy nie widzą innego horyzontu jak tylko mnożenie dóbr i zastępowanie ich innymi, lepszymi. Jest to tak zwana „cywilizacja spożycia”, konsumpcjonizm. Niesie on za sobą mnóstwo odpadów i rzeczy do wyrzucenia. Przedmiot zostaje odrzucony, bez uświadomienia sobie jego trwałej wartości. Posiadanie samych dóbr nie doskonali człowieka, nie przyczynia się do wzbogacania jego „być”. Zło nie polega na „mieć”, ale na takim posiadaniu, które nie uwzględnia jakości i uporządkowanej hierarchii posiadanych dóbr, hierarchii, która płynie z podporządkowania dóbr i dysponowania nimi „byciu” człowieka (Jan Paweł II 1997: 280).

Człowiek opanowany pragnieniem posiadania i używania, bardziej aniżeli bycia zużywa w sposób nieuporządkowany zasoby ziemi, narażając przez to własne życie. Człowiek mniema, że może samowolnie rozporządzać ziemią, podporządkowując ją bezwzględnie własnej woli, jakby nie miała ona własnego kształtu i przeznaczenia. Człowiek często w swoich działaniach powoduje bunt natury, która jest przez niego tyranizowana (Jan Paweł II 1991: 37). 
Rozwój nie może polegać wyłącznie na bezwzględnym wykorzystywaniu środowiska, nie może zmierzać do nieograniczonego posiadania.

Istotnym postulatem $\mathrm{w}$ formułowaniu nowego stylu życia jest więc kategoria „być" przeciwstawiająca się kategorii „mieć”. W tym miejscu duże znaczenie odgrywa działalność etyczna, duchowa i kulturowa człowieka, w perspektywie których, etyka, religia, kultura, nauka i technika przewidujące swe skutki w trosce o zachowanie i rozwój środowiska przyrody, edukacja, życie rodzinne przeciwstawiają się działaniom nastawionym na zaspokojenie potrzeb czysto konsumpcyjnych. Nowy styl życia charakteryzujący się cechami umiaru, skromności, prostoty życia, nie może ograniczyć się jedynie do postaw indywidualnych nie dostrzegających wymiaru globalnego życia ludzkości.

Ograniczona ingerencja - relacja człowiek - środowisko; to druga zasada ekoetyki - wynikająca bezpośrednio z jakości ludzkiego życia - jest jakość relacji człowieka do środowiska, polegająca przede wszystkim na zredukowaniu maksymalnie działania ludzi w stosunku do przyrody. Ograniczona ingerencja człowieka w świat przyrody mierzona przede wszystkim kategoriami rozumnego rozwoju jawi się jako powinność moralna. Działalność ludzka ingerująca w środowisko przyrodnicze ograniczona jest również przez uznanie wartości i w konsekwencji szacunku dla przyrody i eliminuje postawy bezmyślności i dowolności wykorzystania zasobów naturalnych i przyrody ożywionej.

Środowisko przyrodnicze jako dobro wspólne powinno być trzecią zasadą ekoetyki w rozumieniu otoczenia jako dobra wspólnego.

Związane jest to bardzo silnie $\mathrm{z}$ postawą myślenia planetarnego w podstawowych dziedzinach ludzkiej działalności (polityka, gospodarka, nauka, technika), w których na uwadze należy mieć dobro całej ziemi i całej ludzkości. U jego podstaw znajduje się przekonanie, że żadna grupa społeczna nie może sobie rościć prawa do bycia jedynym podmiotem posiadania dóbr środowiskowych, zwłaszcza że te nie są niewyczerpywalne. „Nikt nie może w sposób absolutny i egoistyczny 
przywłaszczać sobie środowiska, które nie jest res nullius - własnością jednostki, lecz res omnium - powszechną własnością, dziedzictwem całej ludzkości" (Web-01).

Ukazywanie zagrożeń, stawiane wymagania przez nową etykę z konieczności rodzą pytanie o sposób kształtowania właściwej postawy człowieka względem środowiska, uznając jego wewnętrzną wartość przy jednoczesnej trosce o godne życie człowieka. Kształtowanie nowej formy działania jest jednocześnie obowiązkiem względem przyszłych pokoleń, których kosztem nie można osiągnąć dobrobytu chwili obecnej. Podstawą tej odpowiedzialności jest stwierdzenie, że przyszłe pokolenia muszą istnieć, a przygotowanie im warunków życia jest sprawą fundamentalną, mającą swe źródło w uznaniu środowiska za dobro wspólne ludzkości (Jan Paweł II 1991: 37).

\section{Problematyka ekologiczna w podstawie programowej edukacji wczesnoszkolnej, w zakresie edukacji przyrodniczej}

W „Podstawie programowej dla szkół podstawowych”, I etap edukacji, w zakresie edukacji przyrodniczej, zostały podkreślone te obszary, poprzez które w sposób szczególny jest realizowana edukacja proekologiczna.

Uczeń kończący klasę I w zakresie edukacji ekologicznej:

- zna zagrożenia dla środowiska przyrodniczego ze strony człowieka: wypalanie łąk i ściernisk, zatruwanie powietrza i wód, pożary lasów, wyrzucanie odpadów i spalanie śmieci itp.; chroni przyrodę: nie śmieci, szanuje rośliny, zachowuje ciszę w parku i w lesie, pomaga zwierzętom przetrwać zimę i upalne lato,

- wie, że należy oszczędzać wodę; wie, jakie znaczenie ma woda w życiu człowieka, roślin i zwierząt,

- wie, że należy segregować śmieci; rozumie sens stosowania opakowań ekologicznych;

- zna zagrożenia ze strony zjawisk przyrodniczych, takich jak: burza, huragan, powódź, pożar, i wie, jak zachować się w sytuacji zagrożenia. 
Uczeń kończący klasę III w zakresie edukacji ekologicznej:

- obserwuje i prowadzi proste doświadczenia przyrodnicze, analizuje je i wiąże przyczynę ze skutkiem;

- podejmuje działania na rzecz ochrony przyrody w swoim środowisku; wie, jakie zniszczenia w przyrodzie powoduje człowiek (wypalanie łąk, zaśmiecanie lasów, nadmierny hałas, kłusownictwo);

- zna wpływ przyrody nieożywionej na życie ludzi, zwierząt i roślin:

a) wpływ światła słonecznego na cykliczność życia na Ziemi,

b) znaczenie powietrza i wody dla życia,

c) znaczenie wybranych skał i minerałów dla człowieka (np. węgla i gliny) (Web-02).

Podsumowując, główne tematy, poprzez które jest realizowana edukacja ekologiczna w edukacji wczesnoszkolnej dotyczą:

1. zagrożeń dla środowiska przyrodniczego ze strony człowieka poprzez: wypalanie łąk i ściernisk, zatruwanie powietrza i wód, pożary lasów, wyrzucanie odpadów i spalanie śmieci

2. ochrony przyrody: nie śmiecenia, poszanowania zwierząt i rośliny

3. oszczędzania wody

4. segregowania śmieci i stosowania opakowań ekologicznych

5. wpływu przyrody nieożywionej na życie ludzi, zwierząt i roślin:

a) wpływ światła słonecznego na cykliczność życia na Ziemi,

b) znaczenie powietrza i wody dla życia,

c) znaczenie wybranych skał i minerałów dla człowieka (np. węgla i gliny).

Edukacja środowiskowa oznacza przedmiot nauczania i działalność wychowawczą, przygotowującą do rozwiązywania praktycznych problemów środowiskowych przez interdyscyplinarne podejście, poczucie odpowiedzialności oraz czynne włączenie się każdego człowieka i zbiorowości we wspólne działanie (Olaczek 1990: 50).

Edukacja ekologiczna (środowiskowa) jest koncepcją kształcenia i wychowania $w$ duchu poszanowania środowiska przyrodniczego oraz kształtowania poglądów społeczeństwa względem otaczającego świata. Dotyczy rozbudzania wrażliwości na problemy środowiska, poszuki- 
wania przyczyn i przewidywania skutków zjawisk prowadzących do degradacji środowiska naturalnego (Tuszyńska 2006: 18).

Człowiek jest nierozerwalnie związany z przyrodą i wszelka jego działalność ma odzwierciedlenie w otaczającym nas środowisku. Dlatego tak ważną rzeczą jest uświadamianie społeczeństwa w zakresie możliwości i sposobów jak najmniej szkodliwego funkcjonowania i korzystania $z$ dobrodziejstw natury. Taka działalność człowieka nazywana jest w literaturze przedmiotu rozwojem zrównoważonym. Polega ona na „prowadzeniu wszelkiej działalności gospodarczej w harmonii z przyrodą, czyli tak, aby nie spowodować w niej nieodwracalnych zmian" (Cichy 1995: 24). Konieczne jest również uzmysłowienie dalekowzroczności tych działań, ze środowiska korzystamy nie tylko my ale będą też korzystać następne pokolenia.

„(...) Wyodrębniono trzy główne obszary na których należy skoncentrować się przy planowaniu skutecznej strategii osiągnięcia zrównoważonego rozwoju. Są to: ochrona środowiska i racjonalna gospodarka zasobami naturalnymi (m. in. ograniczanie zanieczyszczenia środowiska, ochrona zagrożonych wyginięciem gatunków zwierząt i roślin, promocja odnawialnych źródeł energii), wzrost gospodarczy i sprawiedliwy podział korzyści z niego wynikających (m. in. ułatwienie dostępu do rynków dla państw rozwijających się, finansowanie rozwoju, zmiana nieracjonalnych wzorców konsumpcji i produkcji) oraz rozwój społeczny ( $\mathrm{m}$. in. walka z ubóstwem, dostęp do edukacji, ochrony zdrowia)" (Web-03).

Dla przetrwania ziemi niezbędne jest również kształtowanie świadomości ekologicznej.

Upowszechnianie w społeczeństwie świadomości ekologicznej jest podstawowym warunkiem ekorozwoju. Kształtowaniu tej świadomości służyć powinny wychowanie ekologiczne i powszechna oświata w dziedzinie ochrony środowiska, realizowane przez szkolnictwo różnych szczebli, organizacje i instytucje społeczne oraz środki masowego przekazu (Kaliński 1995: 48). 
Świadomość ekologiczna, rozumiana jako obszar świadomości społecznej odniesionej do środowiska przyrodniczego, przejawia się zarówno w myśleniu, jak i przeżyciach oraz w społecznych standardach pojmowania, przeżywania i wartościowania biosfery. Składnikami świadomości ekologicznej są określone treści, nastawienia oraz emocje, dotyczące środowiska przyrodniczego, powiązane i wzajemnie przenikające się z innymi formami świadomości społecznej (Tuszyńska 2006: 70).

Według H. Skolimowskiego świadomość ekologiczna powinna być:

- holistyczna - otaczający nas świat rozumie jako całość do której należy też człowiek, która posiada cechy organizmu żywego,

- jakościowa - w jedności i nierozerwalności świata widzi przede wszystkim związki jakościowe,

- duchowa - związana $\mathrm{z}$ duchowością człowieka a nie tylko z jego umysłem,

- rewerencja - charakteryzująca się czcią i szacunkiem dla wszystkiego co istnieje,

- uczestnicząca - człowiek aktywnie uczestniczy w życiu naszej planety, nie jest biernym obserwatorem,

- ewolucyjna - „przebieg procesów w kosmosie jest ukierunkowany od jednostajności do różnorodności, od materialności do duchowości, a więc ewolucja kosmosu - jako całości dostępnej ludzkiemu poznaniu - przedstawia zjawisko rozprzestrzeniania się procesów psychicznych, duchowych" (Parlak 2005: 13).

Podłożem świadomości ekologicznej jest wiedza nabyta w szkole i poza nią, tradycja kulturowa określonej grupy społecznej, presja opinii tej grupy, własne doświadczenia itp. Treścią świadomości ekologicznej są m.in.: prawa człowieka do środowiska, znajomość zagrożeń, ich przyczyn i skutków, poczucie własnej odpowiedzialności za stan przyrody, wola działania połączona z wiarą, że warto chronić przyrodę (Tuszyńska 2006: 8).

„(...) Praca nad kształtowaniem świadomości wytworzy kulturę ekologiczną jednostki, na którą złożą się następujące elementy:

- całokształt wiedzy o środowisku przyrodniczym, 
- zdolność dostrzegania specyfiki i złożoności zjawisk przyrodniczych oraz odnajdywania w nich głównych zjawisk, współzależności i prawidłowości,

- gotowość do przejawiania określonych zachowań w stosunku do środowiska przyrodniczego,

- zdolność otwartego, twórczego myślenia, warunkująca podatność na wprowadzenie innowacji gwarantujących zwiększenie bezpieczeństwa ekologicznego,

- ukształtowanie wrażliwości i zdolności postrzegania problemów środowiska we własnej pracy i życiu” (Cichy 1990: 278-285).

Poszerzanie świadomości, uwrażliwianie społeczeństwa oraz angażowanie w działalność ekologiczną powoduje kształtowanie postaw, wartości i niezbędnych umiejętności potrzebnych do wprowadzenia w życie codziennych zasad zrównoważonego rozwoju.

\section{Wnioski}

W szkole jest wiele okazji do rozbudzania wrażliwości ekologicznej. Obejmuje ona działania mające na celu zaznajamianie dzieci ze światem roślin, zwierząt i grzybów z przyrodą nieożywioną, a także nauczenie ich dostrzegania i przeżywania piękna przyrody oraz obcowania z nią.

Szczególną uwagę należy zwrócić na następujące cele edukacji ekologicznej:

- rozwijanie u dzieci szacunku i poczucia odpowiedzialności za stan i pomnażanie zasobów naturalnych środowiska człowieka,

- uwrażliwianie na środowisko przyrodnicze, szacunek do niego,

- racjonalne korzystanie z zasobów przyrody,

- dążenie do kontaktu z nieskażonym środowiskiem,

- sposoby ochrony środowiska naturalnego,

- zaszczepienie potrzeby dostrzegania norm i zakazów ekologicznych,

- kształtowanie nawyków kultury ekologicznej,

- kształtowanie poczucia moralnej i obywatelskiej odpowiedzialności za ochronę dóbr przyrody, 
- wdrażanie umiejętności interdyscyplinarnego myślenia i rozumowania,

- nauczanie postrzegania zależności między stanem środowiska, a jakością życia każdej jednostki ludzkiej i całych społeczeństw,

- kształtowanie nawyków międzynarodowej solidarności w ochronie środowiska.

Autorskie programy bardzo rzetelnie spełniają cele edukacji ekologicznej. Inaczej jest z podręcznikami. Mimo iż pojawiają się tematy z zakresu ekologii, to jest ich jeszcze zbyt mało. Ponadto podręczniki koncentrują się na teoretycznych aspektach problemu. Niewiele miejsca poświęca się na eksperymenty, badania, obserwacje oraz zajęcia $\mathrm{w}$ terenie, a przecież to właśnie metody aktywizujące ucznia przynoszą najlepszy efekt w przyswajaniu wiedzy.

\section{Zakończenie}

Nauczanie i wychowanie powinno kształtować postawę wartości ekologicznej oraz poczucie moralnej odpowiedzialności za naturę. Świat przyrody daje człowiekowi niezwykle cenne dobra, a mimo to, często przyroda bywa traktowana w sposób przedmiotowy. Jaki będzie los naszej Planety zależy w dużym stopniu od umiejętności i skuteczności kształcenia i wychowania.

W edukacji ekologicznej stworzenie właściwego programu nauczania i wychowania jest podstawowym warunkiem jej skuteczności. Istotne też są baza dydaktyczna, działalność instytucji i organizacji wspomagających pracę nauczycieli, a przede wszystkim sam nauczyciel. Powinien on posiadać odpowiednie przygotowanie merytoryczne oraz przeświadczenie o konieczności proekologicznego kształcenia i wychowania. To właśnie nauczyciel uczy dzieci żyć w zgodzie z przyrodą, racjonalnie korzystać z jej dóbr, chronić przed dewastacją i zanieczyszczeniami. Powinien uwrażliwić dzieci na piękno przyrody oraz na negatywną i niszczycielską działalność człowieka (Web-04).

Ważną rolę w edukacji proekologicznej odgrywają środki masowego przekazu: radio, telewizja, prasa. Niestety informacja naukowa 
i popularnonaukowa kierowana jest do wąskiego grona odbiorców. Wymaga ona refleksyjnej analizy. Ponadto literatura ta znajduje się wciąż na marginesie krajowej działalności wydawniczej. Opracowania statystyczne posiadają najbardziej ograniczone oddziaływanie informacyjne. Skuteczność powszechnej edukacji ekologicznej w znacznym stopniu zależy od rozwoju nowoczesnych form przekazu informacji. Nieoceniona jest rola muzeów przyrodniczych, ogrodów botanicznych i zoologicznych, ścieżek dydaktycznych jak również olimpiad ekologicznych (Web-05).

Edukacja ekologiczna powinna dotyczyć każdego zakresu i wszystkich poziomów oświaty, posiadać charakter całościowy, rozciągać się na całe życie człowieka. Dopiero taka edukacja ma sens. Wpływa bowiem na uświadamianie i kształtowanie proekologicznych postaw ucznia.

\section{Bibliografia}

\section{Literatura}

Cichy D., 1990, Koncepcje społecznej edukacji ekologicznej, Biologia w Szkole, nr 5, s. 278-285.

Cichy D., 1995, Skuteczność kształcenia dla ekorozwoju, Biologia w Szkole, nr 5, s. 236-240.

Jan Paweł II, 1991, Centesimus annus, wyd. TUM, Wrocław.

Jan Paweł II, 1993b, Dialog między nauka a wiara. Wizyta $w$ międzynarodowym centrum naukowym im. Ettore Majoramy, 8.5.1993, L 'Osservatore Romano, 14(1993)7.

Jan Paweł II, 1997, Encyklika Solicitudo rei socialis, wyd. TUM, Wrocław.

Jan Pawęł II, 1993a, „Pragnę” (J19,28), Orędzie na Wielki Post 1993, L Osservatore Romano (wyd. pol.), 14(1993)4.

Kaliński M., 1995, Edukacja ekologiczna forma przystosowania obronnego, Edukacja i Dialog, nr 6, s. 46-54.

Olaczek R., 1990, Międzynarodowa Strategia Edukacji Środowiskowej, wyd. LOP, Warszawa. 
Parlak M. 2005, Edukacja ekologiczna w procesie kształcenia wczesnoszkolnego - założenia, program, propozycje metodyczne, wyd. WP-ZNP, Kielce.

Podrez E., 1991, Kryzys ekologiczny jako problem moralny, w: Rembiałkowska E. (red.), „Etyczne, społeczne i ekologiczne uwarunkowania rozwoju rolnictwa", wyd. AGRA, Warszawa, s. 78-82.

Skrzeszewski Cz., 1981, Własność. Zagadnienia społeczno-moralne, „Słowo. Dziennik katolicki”, s. 221-232.

Sutor B., 1994, Etyka polityczna. Ujęcie całościowe na gruncie chrześcijańskiej nauki społecznej, tłum. A. Marcol, wyd. Kontrast, Warszawa. Tuszyńska L., 2006, Edukacja ekologiczna dla nauczycieli i studentów, wyd. WSP-TWP, Warszawa.

\section{Witryny internetowe}

(Web-01) Paweł VI, List do sekretarza generalnego Konferencji Narodów Zjednoczonych w Sztokholmie Maurycego Stronga, http:// www.wtl.us.edu.pl/e107_plugins/wtl_ssht/index.php?nume$\mathrm{r}=13 \& \mathrm{str}=139-151$, dostęp: 17.04.2013.

(Web-02) http://bip.men.gov.pl/men_bip/akty_prawne/rozporzadzenie_20081223_zal_2.pdf, dostęp: 04.01.2011.

(Web-03) http://www.poznajmyonz.pl/index.php?document=41, dostęp 30.08.2009.

(Web-04) http://www.awans.net/strony/wychowanie_przedszkolne/ orlowska/orlowska2.html, dostęp 17.04.2013.

(Web-05) http://www.awans.net/strony/ekologia/jednak/jednak1.htm, dostęp 10.01.2011. 